\author{
Artur Jochlik \\ Uniwersytet Śląski w Katowicach \\ (D) https://orcid.org/0000-0001-8672-6272
}

\title{
Nieobecność problemu rzeczy samej w sobie w filozofii Hegla w obliczu Heglowskiego rozumienia prawdy
}

\author{
The absence of the problem of the thing in itself in Hegel's philosophy \\ in the face of Hegel's understanding of truth
}

\begin{abstract}
The article presents a Hegelian view of Kant's thing in itself in regard to Hegel's understanding of truth. In it, I designate eight key fragments of The Phenomenology of Spirit, around which the analysis of the issue takes place. As a result, the boundaries have been defined in which Hegel wants to pursue his deliberations. Hegel does not want to think about what is independent of the cognizing subject, claiming that it does not concern us, philosophers, because it is the task of religion. The truth for Hegel is what realizes itself among us, so that it is fully available to us.
\end{abstract}

Keywords: Hegel, thing in itself, truth

\section{Wstęp}

Celem niniejszego artykułu jest wyjaśnienie Heglowskiej niechęci wobec zagadnienia rzeczy samej $\mathrm{w}$ sobie. Teza brzmi: Nie ma miejsca na Kantowskie zagadnienie rzeczy samej w sobie u Hegla, bo nie pozwala na 
to Heglowskie rozumienie prawdy. W odniesieniu do Heglowskiego spojrzenia na to zagadnienie pamiętamy o tym, że mamy typowo ludzki umysł, który tak, a nie inaczej, zmuszony jest interpretować dane. Nie jesteśmy w stanie myśleć i postrzegać inaczej jak na sposób typowo ludzki. Jaka jest rzecz niezależna od poznającego, nie wiemy. Być może jest bardzo podobna do zjawiska, być może nie. Jednak filozofii spekulatywnej nie interesuje żadne „być może”, jako że wiedza nie dotyczy prawdopodobieństwa. Skoro tak, to po co w ogóle zaprzątać sobie głowę rzeczą samą w sobie? Jest to obszar mglistych rozważań związanych z wyobrażeniem, odpowiedni dla myślenia religijnego. Nie dotyczy myślenia pojęciowego tak samo, jak nie dotyczy myślenia pojęciowego zagadnienie społeczne sprzed okresu historycznego (sprzed okresu pisma), oraz zagadnienie przyszłości. Badamy świadomość na sposób historyczny, badamy przyrodę mającą związek ze świadomością oraz badamy samo czyste myślenie. To wszystko, o czym chce mówić Hegel. Świadomość tego pozwoli nam, badaczom historii filozofii nowożytnej, lepiej zrozumieć kwestię recepcji koncepcji rzeczy samej w sobie po śmierci Kanta.

\section{To, na co należy zwrócić uwagę}

Fenomenologia ducha zawiera kluczowe zdania, które należy uważnie rozpatrzyć, aby wyjaśnić niniejsze zagadnienie. Oto one: Z1: „Dlatego takie zajmowanie się celami czy rezultatami, jak też różnicami [między nimi] i ocenami jednych i drugich jest pracą łatwiejszą, niż by się mogło wydawać. Zamiast bowiem zajmować się rzeczą samą, postępowanie takie ma ją zawsze za sobą; zamiast przebywać w rzeczy i zapomnieć w niej o sobie, taka wiedza chwyta się zawsze czegoś innego i - zamiast trzymać się rzeczy [bei der Sache] i całkowicie jej się oddać — pozostaje raczej u siebie samej [bei sich selbst]”. Z2: „To, co przedtem było rzeczą samą, jest jeszcze tylko śladem; jej postać jest osłonięta i zaznacza się tylko jako pewien odcień" ${ }^{2}$. Z3: „Zjawisko [die Erscheinung] jest powstawaniem i przemijaniem, które samo nie powstaje i nie przemija, lecz jest czymś samym w sobie i stanowi rzeczywistość i ruch życia prawdy”. Z4: „Prawda jest nie tylko sama

1 G.W.F. Hegel: Fenomenologia ducha. Tłum. Ś.F. Nowicki. Warszawa 2010, s. 15.

2 Ibidem, s. 29.

3 Ibidem, s. 40. 
w sobie całkowicie równa pewności, lecz ma także postać pewności samej dla siebie, albo inaczej mówiąc: prawda ta ma w swoim istnieniu [Dasein] [...] formę wiedzy o sobie samym”. Z5: „Tak więc w wiedzy [absolutnej] duch zakończył ruch swego kształtowania się jako takiego [...] i osiągnął czysty element swego istnienia [Daseins] — pojęcie”. Z6: „Prawda jest całością”6. Z7: „Występowały po sobie kolejno dwie strony, jedna, w której istota, czyli prawda, miała dla świadomości określoność bytu, oraz druga, w której miała ona określoność bycia tylko czymś dla niej. Ale obie [strony] sprowadzały się do jednej prawdy, że to, co jest, czyli to, co samo $w$ sobie, jest tylko o tyle, o ile jest dla świadomości, a to, co jest dla świadomości, jest też samo $w$ sobie. Świadomość, która jest tą prawdą, ma tę drogę za sobą i nie pamięta o niej, kiedy występuje bezpośrednio jako rozum, czyli ten występujący bezpośrednio rozum występuje tylko jako pewność owej prawdy. W rezultacie tylko zapewnia, że jest wszelką realnością, ale sam tego nie pojmuje; pojmowaniem tego bezpośrednio wyrażonego twierdzenia jest bowiem właśnie owa zapomniana droga"7. Z8: „Dopiero wtedy, kiedy rozum występuje jako refleksja [powracając] od tej przeciwstawnej pewności [do siebie], jego twierdzenie o sobie występuje nie tyko jako pewność i zapewnienie, lecz jako prawda; i to nie [jako jakaś prawda] obok innych [prawd], ale jako [prawda] jedyna" ${ }^{\prime}$.

\section{Kant}

Kant bardzo wcześnie udowodnił, że zamierza zupełnie inaczej podchodzić do filozofii w interesującej nas kwestii, niż zrobią to później idealiści niemieccy. Napisał bowiem już w 1747 roku: „Ponieważ nie można powiedzieć, że coś jest częścią pewnej całości, jeżeli nie pozostaje w związku z pozostałymi częściami [...], świat zaś jest rzeczywiście złożoną istotą, to substancja, która $\mathrm{z}$ żadną rzeczą $\mathrm{w}$ całym świecie nie pozostaje $\mathrm{w}$ związku, nie należy również do świata, jest przeto czymś jedynie w myśli, to znaczy

\footnotetext{
4 Ibidem, s. 508.

Ibidem, s. 514.

6 Ibidem, s. 23.

7 Ibidem, s. $164-165$.

8 Ibidem, s. 165.
} 
nie przedstawia sobą żadnej części tego świata"9. Wymierzone to ma być przeciwko tym, którzy twierdzą, że „nie może istnieć nic poza jednym jedynym światem" ${ }^{\prime 10}$. To jest jednak dokładnie stanowisko Hegla. Hegel nie będzie udowadniał, że taka rzecz nie jest możliwa, lecz zwyczajnie nie podejmie kwestii. Hegel w różnych miejscach swych dzieł (np. w Przedmowie do Fenomenologii ducha, w logice istoty Nauki logiki, w drugiej części Encyklopedii nauk filozoficznych) zainteresowany jest relacją całości do części, nie podejmuje tam jednak nigdzie explicite kwestii tego, co miałoby nie pozostawać $\mathrm{w}$ relacji z niczym innym. Kiedy więc, dla przykładu, Hegel pisze: „Nie tylko, że filozofia musi być zgodna z doświadczeniem przyrodniczym, lecz empiryczna fizyka stanowi ponadto przesłankę poprzedzającą i warunek powstania i rozwoju nauki filozoficznej. Ale czymś innym jest proces powstawania jakiejś nauki i prowadząca do niej praca przygotowawcza, a czymś innym nauka sama; nie mogą już one w niej występować jako podstawa, którą ma tu być raczej konieczność pojęcia"11, to jest jasne, że ani empiryczna fizyka, ani pojęcie tego nie rozpoznaje ${ }^{12}$. Metoda uchwycona jest jako struktura całości, która uwzględnia stawanie się, swój własny powrót, swe własne rozdzielenie i jednoczenie, swą własną tymczasowość definicji absolutu ${ }^{13}$. Wykraczanie jest jego własnym wykraczaniem, zewnętrzność jego własną zewnętrznością, transcendencja jego własną świadomością religijną, początek jego powrotem, jego koliskiem. Tym samym das Ganze to nie po prostu to, co zostaje zusammengesetzt, lecz jest to pojęcie, które się rozwija. Krótko mówiąc, nie ma miejsca na Kantowską sugestię w konsekwentnym monizmie ${ }^{14}$. Zostaje to najlepiej wyrażone w następujących słowach: „Filozofię Kantowską można w sposób najbardziej konkretny określić tak, że ducha ujęła ona jako świadomość i dlatego wszelkie określenia, jakie ona zawiera, należą wyłącznie do feno-

9 I. Kant: Dzieła zebrane: Tom I. Pisma przedkrytyczne. Tłum. Translatorium Filozofii Niemieckiej Instytutu Filozofii UMK. Toruń 2010, s. 32. Kant podejmuje ponownie to zagadnienie w $\S 21$ De mundisensibilis (ibidem, s. 839-340). Tam już jednak bardziej wyraźnie skłania się ku stanowisku, że winniśmy założyć istnienie spójnego świata, by móc zajmować się przyrodoznawstwem.

10 Ibidem, s. 33.

11 G.W.F. Hegel: Encyklopedia nauk filozoficznych. Tłum. Ś.F. Nowicki. Warszawa 2014, s. 262 (§ 246Z).

12 A co duch rozpozna, choćby transcendencję w świadomości nieszczęśliwej, to ostatecznie jest i tak jego.

13 "There is no reason, Hegel holds, why distrust of truth should not itself be distrusted". J. Loewenberg: Hegel's Phenomenology: Dialogues on the Life of Mind. La Salle 1965, s. 9.

14 Zob. A. Noras: Kant i Hegel w sporach filozoficznych osiemnastego i dziewiętnastego wieku. Katowice 2007, s. 34. 
menologii, a nie do filozofii ducha. Traktuje ona $J a$ jako odnoszenie się do czegoś leżącego po drugiej stronie, co w swym abstrakcyjnym określeniu nosi nazwę rzeczy samej w sobie, i tak inteligencję, jak i wolę ujmuje tylko w tym skończonym wymiarze. Bo jeśli nawet w pojęciu refleksyjnej władzy sądzenia dochodzi ona do idei ducha, do podmiotowości-przedmiotowości, do ogladajacego intelektu itd., jak również do idei przyrody, to sama ta idea jest na powrót zdegradowana do poziomu zjawiska, a mianowicie do poziomu pewnej subiektywnej maksymy (zob. § $58 \mathrm{Wstępu}^{15}$ )".

\section{$\mathrm{Z} 1-\mathrm{Z} 3$}

Wspomniana rzecz z Z1 jest tym, co wyczerpuje się w swej realizacji ${ }^{16}$. Rzecz przemija, ulega zniesieniu, a więc zostanie zachowana w tym, co nowe - w swej realizacji - tylko pod pewnym względem. Czy chodzi tu o rzecz jako o to, co materialne (o donicę, kilim lub agrafkę), czy też chodzi tu o rzecz jako o daną filozoficzną kwestię (relacja umysł-ciało, granice wszechświata)? To bez znaczenia ${ }^{17}$, bo Hegel wyraża to, że rzecz nie jest niczym sama w sobie bez podmiotu ${ }^{18}$. Rzecz jest czymś w sobie dla nas. To my wyobrażamy sobie kosmos pozbawiony obserwatora. Owo my, ów duch, jest czymś, co interesuje Hegla, nie kapryśność pojedynczego umysłu ludzkiego. Tym, czym rzecz jest $\mathrm{w}$ sobie, co oznacza $w$ swej istocie ${ }^{19}$, to tym właśnie, czym jest dla innego ${ }^{20}$. Początkowo ta realizacja pojawiła się w Oświeceniu, w tym, powiemy dzisiaj, preludium pozytywizmu. Rzecz uchodziła tam mianowicie za to, co przede wszystkim użyteczne ${ }^{21}$. Jednak nabrało to swego pełnego znaczenia $\mathrm{w}$ bezpośredniej recepcji filozofii Kanta, w idealizmie niemieckim jako kulminacji historii filozofii (patrząc z perspektywy Hegla). Rzecz sama w sobie, jeśli rozpatrywana w ramach filozofii, a nie w ramach religii (na przykład jako Lutrowski Deus abscon-

15 G.W.F. Hegel: Encyklopedia nauk filozoficznych. Tłum. Ś.F. Nowicki. Warszawa 2014, s. 440 (§ 415Z).

${ }^{16}$ G.W.F. Hegel: Fenomenologia ducha..., s. 15.

17 Przynajmniej na tym wstępnym etapie rozważań Fenomenologii ducha.

18 Ibidem, s. 501.

19 Ibidem, s. 26.

20 Ibidem, s. 501.

${ }^{21}$ Ibidem. 
ditus), jest nieporozumieniem. Rzecz jest tym, czym jest dla myślenia. Tym, czym miałaby być poza myśleniem, nie dotyczy myślenia filozoficznego. Tak jak obserwuję granicę lasu, bo tu jest las, a tam łąka, tak jak obserwuję granicę sprawiedliwości, bo tu jest sprawiedliwość, a tam korupcja, tak pragnę obserwować granicę poznania, bo tu jest poznanie, a tam... jak rozumowo określić to, co jest „tam”? Jeśli nie można tego uczynić, niech zajmą się tym artyści i kapłani ${ }^{22}$. Rola filozofii religii, w przeciwieństwie do samej religii, jest tutaj skromna: „Zadaniem filozofii religii jest poznanie logicznej konieczności w postępie określeń istoty poznanej jako Absolut, którym to określeniom odpowiada najpierw typ kultu, a następnie również świecka samowiedza, świadomość tego, co stanowi najwyższe powołanie człowieka; a zatem natura etyczności danego narodu, zasada jego prawa, jego rzeczywistość wolności i jego ustroju, a także jego sztuki i nauki, odpowiadają zasadzie, która stanowi substancję danej religii. Zrozumienie tego, że wszystkie te momenty rzeczywistości danego narodu stanowią jedna systematyczną totalność i że stwarza je i kształtuje jeden duch, leży u podstawy zrozumienia następnej rzeczy, a mianowicie tego, że dzieje religii zbiegają się $\mathrm{w}$ jedno $\mathrm{z}$ powszechnymi dziejami świata ${ }^{23}$ ". Potrzeba sztuki zaznacza się przede wszystkim $\mathrm{w}$ religiach innych niż chrześcijaństwo, aby zapełniła ich duchowy niedowład, ich brak podkreślenia aspektu wolności, gdzie jest ,stopniem na drodze do wyzwolenia ${ }^{24 \%}$. To nie oznacza zatem, oczywiście, że religia jest czymś godnym drwiny. Wiele ciepłych słów usłyszymy z ust Hegla na temat religii na jego wykładach z filozofii religii, na przykład: „To, co budzi w nas wątpliwość i trwogę, wszelkie zmartwienie, wszelką troskę, wszelkie ograniczone zainteresowania skończonością, pozostawiamy na mieliźnie doczesności; i jak na najwyższym wierzchołku pasma górskiego, odległego od wszelkiego określonego widoku tego, co ziemskie, [pogrążeni] w spokoju nie zwracamy uwagi na wszelkie ograniczenia krajobrazu i świata, tak samo wówczas, gdy człowiek patrzy okiem duchowym, uwolniony od twardości tej rzeczywistości, traktuje ją tylko jako jakiś pozór, który w tym czystym rejonie jedynie odzwierciedla swoje odcienie, różnice i światła w promieniu duchowego słońca, doprowa-

22 Tę interpretację można kwestionować, powołując się na wypowiedź Hegla o jedności treści religii i filozofii, różnicy formy (G.W.F. HeGEL: Encyklopedia nauk filozoficznych..., s. 571 (§ 573Z)). Należałoby najzwyczajniej odpowiedzieć, że to, o czym tu piszę, widocznie dotyczy różnicy formy. Nietrudno zauważyć, że Hegel odcina się od podejmowania kwestii zaświatów i transcendencji. „W filozofii wiadomo bliżej, że z określenia natury Boga da się wyprowadzić określenie jego stosunku do świata" (ibidem, s. 579 $(\S 573 Z)$ ).

${ }^{23}$ Ibidem, s. $562-563(\S 562 Z)$.

24 Ibidem, s. $563-564$ (§ 562Z). 
dzone do łagodności wiecznego spokoju"25. Uzasadnienie tego odnajdziemy w adnotacji do § 63 Encyklopedii nauk filozoficznych. Gdy cofamy się jednak do tego systemowego początku, jaki stanowi Z1, ta kwestia religii, jak i wszystkie inne kwestie, przyjmuje ciągle jeszcze postać prostej rzeczy (die Sache), co do której zostajemy przekonani, że nie jest ona wartościowa jako skarb na końcu drogi, tym bardziej również nie jako wystrzał z pistoletu natchnienia ${ }^{26}$, ale jako sama droga. „To stawanie się nauki $w$ ogóle, czyli wiedzy, przedstawia właśnie niniejsza fenomenologia ducha. Wiedza [taka], jaką jest na początku, czyli duch bezpośredni, jest tym, co pozbawione ducha, jest świadomościa zmysłową. Żeby stać się wiedzą właściwą, to znaczy, żeby wytworzyć ten element nauki, którym jest samo jej czyste pojęcie, musi ona przejść długą i żmudną drogę" ${ }^{27}$. To zapowiedź późniejszego podkreślenia znaczenia historii (tym bardziej, że akapit dalej Hegel pisze, że chodzi mu o ,jednostkę ogólną”, das allgemeine Individuum, nie „poszczególną jednostkę", das besondre Individuum ${ }^{28}$ ), a rozwinięcie zapowiedzi odsłania przed nami Z2. Rzecz nabiera nowego znaczenia jako czegoś, co będąc jawnym, obecnym, przybiera postać skrytą, będącą odcieniem czegoś nowego. Rzecz jest tym, co popada w przeszłość, co tylko dlatego nie popada $\mathrm{w}$ zapomnienie, gdyż nad nią stoi duch wyższy niż ten, który był obecny, gdy ona była obecna ${ }^{29}$. A duch ten jest niczym innym, niż tym, czemu przeznaczone jest - skoro wiemy, że już się to wydarzyło — rozwinięcie się do postaci nauki ${ }^{30}$, gdzie duch zna siebie jako ducha ${ }^{31}$, bo poza sobą rozpoznaje wciąż siebie ${ }^{32}$, tak, aby kiedyś powiedzieć: „To, co my we wspomnieniu (Erinnerung) obejmujemy krótkim rzutem oka, w rzeczywistości rozciąga się na ten długi czas" ${ }^{33}$. To natomiast nas prowadzi do Z3, do zjawiska. Czym, moglibyśmy pomyśleć, jest to, co się zjawia, jeśli nie tym, co rozczarowuje, jeżeli chodzi o brak swej trwałości? Moglibyśmy narzekać na kruchość tego, co nas otacza i w związku z tym napominać ludzi, by

${ }^{25}$ G.W.F. Hegel: Wykłady z filozofii religii, Tom I. Tłum. Ś.F. Nowicki. Warszawa 2013, s. 4-5.

${ }^{26}$ G.W.F. Hegel: Fenomenologia ducha..., s. 28.

27 Ibidem.

28 Ibidem, s. $28-29$.

29 „Real knowledge is but another name for apparent knowledge purged of presumption and transfigured into truth". J. Loewenberg: Hegel's Phenomenology: Dialogues on the Life of Mind..., s. 13.

${ }^{30}$ „Absolutna wiedza to wiedza o przeciwieństwie w jedności i o jedności w przeciwieństwie; a nauka to wiedza o tej jedności w jej całym samoistnym (durchsichselbst) rozwoju" (G.W.F. HeGel: Wykłady z historii filozofii, Tom III..., s. 655).

31 G.W.F. Hegel: Fenomenologia ducha..., s. 27.

32 Ibidem, s. 26.

33 G.W.F. Hegel: Wyktady z historii filozofii, Tom III..., s. 650. 
pamiętali o tym, co wieczne; ale to nie jest podejście Hegla. W Z3 zaskakujące jest to, że to samo zjawisko ma być tym, co stanowi odstępstwo od przemijalności. Jak to możliwe? Hegla interesuje to, co samo się ustanawia, das Sichselbstsetzende ${ }^{34}$. Interesuje go to dlatego, że nie chce rozważać świata w taki sposób, aby oceniać go, przykładając do niego stały wzorzec etycznych wartości. Nie chce mieć tu do czynienia z owym oklepanym: jest tak a tak, powinno być siak, a więc caly świat jest zepsuty, dawniej byto lepiej. Alternatywą dla tego spojrzenia nie musi być moralny relatywizm. Może nią być historyczny rozwój świadomości naszej wolności. A na jakiej podstawie ludzie uświadamiają sobie własne zniewolenie, tak iż pragną wolności? Czy nie dzieje się tak na podstawie jakiegoś trwałego wzorca, jakiejś nieśmiertelnej idei tkwiącą $\mathrm{w}$ ich umysłach? Nie - i z pewnością nie tak Hegel rozumie ideę. Hegel oczekuje od idei, aby ,jedno i to samo ukształtowało samo siebie w sposób zróżnicowany"35", a nie żeby to, co rzekomo już ukształtowane, porównywane było ze wszystkim na sposób zewnętrzny, aby wydobyć tym samym jakieś głębsze prawdy z tego, co przypadkowe ${ }^{36}$. Hegel oczekuje czegoś od idei, nie od pomysłowej wyobraźni natchnionego człowieka $^{37}$. Oczekuje czegoś od rzeczy, by ta cały czas ukazywała sobą więcej, niż dała na początku - oczekuje otwarcia na aspekt podmiotowy, tak jak będzie oczekiwał od rozważania o podmiocie otwarcia na aspekt przedmiotowy. Oczekiwanie to nie jest niczym rewolucyjnym, bo dane jest już w Systemie idealizmu transcendentalnego Schellinga. Różnica polega tylko na tym, że Hegel rozpozna w ustaniu tego ukazywania się, tego przejawiania się - w tej nocy, w której wszystkie krowy są czarne - fałsz. To właśnie wyraża Z3. To wyjście od rzeczy, która rzekomo nie zawiera podmiotu, a później, jeżeli już gdzieś podmiot jest obecny, to go nie potrzebuje do tego, by być tą samą rzeczą ${ }^{38}$, jest niczym innym, jak wyjściem

${ }^{34}$ G.W.F. Hegel: Fenomenologia ducha..., s. 39.

35 Ibidem, s. 21.

36 Ibidem.

37 „What Hegel does is to reduce to the level of mere assurances all assumptions; one assurance, he maintains, is as good as another. More than assurance, however, is the fact that knowledge occurs". J. Loewenberg: Hegel's Phenomenology: Dialogues on the Life of Mind..., s. 9.

38 „Pewność zmystowa za sprawą swej konkretnej treści może się bezpośrednio jawić jako poznanie najbogatsze, ba, jako poznanie o bogactwie nieskończonym, [bogactwie,] które nie ma żadnej dającej się znaleźć granicy, zarówno wtedy, gdy posuwamy się coraz dalej [hinaus] w przestrzeni i w czasie, w których się ono rozciąga, jak i wtedy, gdy bierzemy sobie z tej obfitości jakąś cząstkę i przez dzielenie wchodzimy w nia coraz głębiej [hineingehen]. Ponadto poznanie to [się] jawi się jako poznanie najprawdziwsze; nie utraciło bowiem jeszcze nic z przedmiotu, lecz ma go przed sobą w całej pełni. Faktycznie jednak ta pewność sama podaje się za prawdę najbardziej abstrakcyjną i najuboższą. Wyrazem jej wiedzy o rzeczy [von dem, was się weiß] jest tylko to [es] jest; i jej prawda 
od pierwszych dwóch rozdziałów Fenomenologii ducha ${ }^{39}$. Hegel mierzy się z tym, co tymczasowo, na różne sposoby, raz za razem uchodziło za prawdę. W samym mierzeniu się odnalazł prawdę, jakiej szukał.

\section{Z4-Z6}

Pytanie sprowadza się do tego, czy Hegel uznawał, jakoby jemu samemu prawda wymykała się spod kontroli i dlatego jakoby stosuje upraszczająca siatkę pojęciową, którą, niczym siecią, pragnie uchwycić rzeczywistość, nie zważając na to, ile wody z niej ucieknie. Otóż nie. Chociaż znane jest powiedzenie, że każdy jest dzieckiem swojej epoki, nic nie wskazuje na to, aby ten aspekt przykuwał na dłużej jego uwagę. Nie, prawdę uchwycisz w jej nagości — ślad jej bosych stóp — o ile oboje, ty i prawda, jesteście $\mathrm{w} \mathrm{ruchu}^{40}$. Bez podkreślenia tego łatwo o zarzut, że historyczny proces pogłębiania naszej wiedzy jest czymś tylko subiektywnym. $Z$ jednej strony

zawiera tylko byt rzecz [der Sache]; świadomość ze swej strony występuje w tej pewności tylko jako czyste $J a$; czyli $J a$ występuję w niej tylko jako czysty Ten Oto, a przedmiot również tylko jako czyste To Oto” (ibidem, s. 73). „Taka właśnie jest charakterystyka rzeczy [stanowiącej przedmiot] postrzeżenia; a świadomość jest określona jako świadomość postrzegająca [czyli »biorąca« prawdę] [als Wahrnehmendes], o ile jej przedmiotem jest ta rzecz; świadomość ma ten przedmiot tylko brać [nehmen] i zachowywać się jako czyste ujmowanie [reines Auffassen]; tym, co otrzymuje ona dzięki temu, jest to, co prawdziwe [das Wahre]. Gdyby sama zachowywała się przy tym braniu [bei diesen Nehmen] w sposób aktywny, prawda [die Wahrheit] zostałaby przez takie dodawanie albo pomijanie zmieniona. Ponieważ przedmiot jest tym, co prawdziwe i ogólne, tym, co sobie równe, świadomość zaś jest dla siebie tym, co zmienne i nieistotne, więc może się jej zdarzyć, że ujmie przedmiot niewłaściwie i ulegnie złudzeniu. Świadomość postrzegająca [das Wahrnehmende] ma świadomość możliwości złudzenia" (ibidem, s. 86).

39 Pęknięcie następuje dopiero w tym miejscu: „Ta bezwarunkowa ogólność, która jest teraz prawdziwym przedmiotem świadomości, istnieje jeszcze jako jej przedmiot; nie uchwyciła ona jeszcze swojego pojęcia jako pojęcia. Jedno od drugiego należy w istotny sposób odróżnić; dla świadomości przedmiot ze stosunku do czegoś innego wycofał się do siebie i tym samym stał się sam w sobie pojęciem; ale świadomość nie jest jeszcze dla siebie pojęciem i dlatego w owym skierowanym refleksyjnie [ku sobie] przedmiocie nie rozpoznaje siebie" (ibidem, s. 97).

40 A to wokól, to, co niezwiązane ze śladami? Tu wystarczy przypomnieć sobie o kapryśności przyrody z drugiej części Encyklopedii. To nas, filozofów spekulatywnych, mało co obchodzi. To, że prawda jest całością nie oznacza, że wszystko nabrało jednakowego znaczenia, jak być może ma to miejsce w fenomenologii Husserla. Kontemplacja rzeczy 
mielibyśmy tylko proces, niepewny niczym ruch pijanego po zmierzchu, $\mathrm{z}$ drugiej trwałą prawdę, to, co jest, to, co pozostaje niewzruszone. Jak wiedza nasza miałaby się mierzyć z takim spokojem tego, co prawdziwe inaczej, niż poprzez jakąś wschodnią kontemplację? Chyba tylko z pomocą filozofii tożsamości, ale jej słabością jest to, że mimowolnie tworzy drugi świat, ucieka od tego świata. Jednak poprzez ukazanie ruchu prawdy i filozofa w ruchu za nią wskazujemy, że nasza myśl skierowana jest na to, co samo - jako substancja, causa sui, jako to, co radziło sobie bez nas ulegało rozwinięciu. Przekształcenie tego nieświadomego swego znaczenia ruchu w fenomenologię jest niczym innym, jak osławioną substancją, która musi stać się podmiotem ${ }^{41}$. A my nie musimy specjalnie trudzić się w uzasadnianiu tego ruchu. Jedyne, co musimy zrobić, to zacząć uczyć (i uczyć się) historii filozofii. Możliwość spojrzenia sub specie aeternitatis okazała się mrzonką ${ }^{42}$; a jednak sama historia to za mało, stąd nasze rozważania o prawdzie, które chce być czymś bardziej subtelnym, niż sloganem: „,prawda jest tym, co historyczne". Nie mamy do czynienia z czymś przypadkowym, lecz z rozwojem uporządkowanym. Co stanowi o tym uporządkowaniu? Metoda. Gdzie odnajdę metodę? We mnie. Zaiste, stąpamy jedynie, tropiąc ślady, ale nie odległość przykuwa naszą uwagę, lecz to, że stają się naszymi śladami. Ta droga była już za tobą, od dawna była gotowa. Ale przed tobą, w punkcie, od którego zacząłeś się cofać, droga jeszcze nie jest gotowa. Nadawanie znaczenia ma miejsce wyłącznie w obrębie tego, co było, ale ponieważ Hegel wie, jaki trop zamierza śledzić - trop wolności - wszystko inne, co zostało podeptane, nabiera uzasadnienia. I teraz dopiero, z tropem wolności na uwadze, przystępujemy do Z4, to nam da uzasadnienie tego, dlaczego prawda jest właśnie taka, jak ją Hegel opisuje. Co wydawało się walką zwróconych przeciwko sobie postaci świadomości, okazuje się momentami całości, której jednak (o czym nie wiedział Schelling) nie wyrazimy inaczej, jak poprzez te momenty, te poszczególne ślady, które przemierzyć możemy (musimy?) zawsze znów od nowa. Tym, co może nie zostać zauważone przy dochodzeniu do Z4 jest to, że pewność powiązana jest $\mathrm{z}$ działaniem ${ }^{43}$. „Dla tego ducha, pewnego w swoim istnieniu [Dasein] samego siebie, elementem istnienia [des Daseins,] [czyli pierwszym momentem,] nie jest nic innego niż właśnie ta wiedza o sobie; wypowiadanie tego, że to, co duch ten czyni, czyni zgodnie z przekonaniem, iż jest to obowiązkiem — ta jego mowa jest tym, co stanowi moc

dla niej samej jest dla Hegla tak samo poważne, jak kontemplacja własnego nosa przez bramina.

${ }^{41}$ Ibidem, s. 22.

42 Czyli zgłębienie Nauki logiki nie jest wystarczające do zrozumienia filozofii Hegla.

${ }^{43}$ Ibidem, s. 501-502. 
obowiazujaca [ist das Geleten] jego działania. - Działanie jest pierwszym mającym byt sam $w$ sobie rozdzieleniem prostoty pojęcia i powrotem $\mathrm{z}$ tego rozdzielenia" obrażania sobie czegoś innego, tutaj [- w rozwoju fenomenologicznym »właściwej« świadomości, który kończy się na »duchu pewnym samego siebie« - ] jest własnym działaniem jaźni. To, że własne działanie [Tun] jaźni jest treścia, jest połączeniem dokonanym przez pojęcie. Pojęcie to jest bowiem — jak widzimy — wiedzą o tym, że działanie jaźni w sobie jest wszelką istotnością i wszelkim istnieniem [Dasein], wiedzą o tym oto podmiocie jako o substancji, a o substancji jako o tej wiedzy o działaniu jaźni [seines Tuns]" ${ }^{\prime 45}$. To powiązanie prawdy, pewności i wiedzy z działaniem może wydawać się zaskakujące. Jak jednak inaczej miałoby nastąpić rozpoznanie siebie $\mathrm{w}$ innym $\mathrm{i}$ innego $\mathrm{w}$ sobie ${ }^{46}$ ? To zaś rozpoznanie jest kluczowe do tego, aby wydostać się z sideł subiektywnego idealizmu, na co już Hegel wskazywał w Differenzschrift oraz Glauben und Wissen; to z kolei było istotne, bo już w Tybindze trójka przyjaciół (Hegel, Hölderlin, Schelling) zdawała sobie sprawę $\mathrm{z}$ tego, że absolut musi zostać ujęty jako jedność obiektywności i subiektywności, a absolut faktycznie musi zostać ujęty, bo bez niego, bez tego, co przez nic nieuwarunkowane, na każdym kroku w naszej argumentacji grozi nam regressus ad infinitum ${ }^{47}$ (tam, gdzie nie chcemy w filozofii wołać na pomoc do Boga, musimy jakoś radzić sobie bez Niego). The stakes are high, jak powiedzieliby Amerykanie. Lecz czy aby na pewno absolut musi zostać ujęty, ,złapany”? To przecież, co przez nic nieuwarunkowane, samo siebie warunkuje, samo siebie określa, czego dowodem jest historia filozofii, już od jej pierwszych koncepcji arché. To samookreślające się pojęcie jest tym, co od czasu Fenomenologii ducha przykuwa uwagę Hegla, a zainspirował go w tym Schelling, który pisał: „Samowiedza jest aktem, ale w każdym akcie coś się dla nas dokonuje. Każde myślenie jest aktem, a każde określone myślenie określonym aktem, jednakże w każdym tego rodzaju akcie powstaje nam również określone

44 Ibidem, s. 503.

45 Ibidem, s. 507.

46 „Truth requires certainty as well as self-certainty, or consciousness and self-consciousness, which, in turn, is equivalent to self-knowledge. For the concept to receive objective form, we must surpass religion. This is a version of the familiar idea that we need to translate our ideas into practice. When we do that, when we realize ourselves in what we do, we have philosophical science as Hegel understands it". T. Rockmore: Cognition: An Introduction to Hegel's Phenomenology of Spirit. Berkeley, 1997, s. 188.

47 Zob. F.W.J. Schelling: System idealizmu transcendentalnego: O historii nowszej filozofii (Z wykładów monachijskich). Tłum. K. Krzemieniowa. Warszawa 2015, s. 37-41. T. Rockmore: Cognition: An Introduction to Hegel's Phenomenology of Spirit. Berkeley 1997, s. $179-180$. 
pojęcie. Pojęcie nie jest niczym innym, jak tylko aktem samego myślenia, a w oderwaniu od tego aktu jest ono niczym. Dzięki aktowi samowiedzy również musi powstać nam jakieś pojęcie; jest nim właśnie pojęcie Ja. Kiedy dzięki samowiedzy staję się dla siebie przedmiotem, wytwarza mi się pojęcie Ja, i odwrotnie, pojęcie Ja jest tylko pojęciem tego stawania się dla siebie przedmiotem"48. Dlaczego zatem Z5 wskazuje na to, że to pojęcie jest czystym elementem istnienia ducha? Bo pojęcie nie jest niczym przypadkowym, odebrało $\mathrm{z}$ wyobrażenia to, co $\mathrm{w}$ wyobrażeniu najbardziej istotne $^{49}$. A duch nie miał do czynienia $\mathrm{z}$ dowolnym wyobrażeniem, lecz $\mathrm{z}$ najbardziej wzniosłym - z wyobrażeniem religii chrześcijańskiej. To zaś wyobrażenie jest najbardziej wzniosłe, bo, jak każda religia, dotyczy tego, co trwałe pośród wszystkiego, co przemija, lecz w przeciwieństwie do pozostałych religii, skupia się na człowieku bez popadania w podkreślanie jego związku z tym, co zwierzęce bez separacji człowieka do Boga (judaizm, islam). A co takiego jest w człowieku tym, co trwałe, a jednocześnie niezwierzęce? Jest to jego samowiedza. Samowiedza, czyli nic innego, jak właśnie wiedza o sobie w innym i wiedza o innym w sobie: ja, czyli my. To przewrotna konkluzja, aby uznać, że samowiedza jest tym, co wymagało wydobycia (również) ze świadomości religijnej, ale dokładnie o tym Hegel pisze w ostatnim rozdziale Fenomenologii ducha. I tu musimy wrócić niemal do początku, do Z6, aby coś ważnego nie umknęło naszej uwadze. Wielu słyszało o Z6, ale nie każdy pamięta, że to zdanie ma swoje rozwinięcie w postaci następnego zdania: „Całością zaś jest tylko istota, która rozwija się i dzięki temu dochodzi do zakończonej postacis" ". Następnie Hegel, wychodząc naprzeciwko tym, którzy obyci są z terminologią Schellinga, tłumaczy, że naturą absolutu jest jego stawanie się sobą ${ }^{51}$, przygotowując ich stopniowo do tego, co padnie na końcu Fenomenologii: „Znający samego siebie duch jest bowiem, właśnie dlatego, że ujmuje swoje pojęcie, bezpośrednią równością z sobą samym, która w swej różnicy jest pewnościa tego, co bezpośrednie" 52 . Zapytajmy więc wprost: Czym jest prawda? Pytanie to pomoże zrozumieć kwestię rzeczy samej w sobie.

48 F.W.J. Schelling: System idealizmu transcendentalnego: O historii nowszej filozofii..., s. $42-43$.

49 Należy zauważyć, że chociaż pojęcie jest tematem Fenomenologii ducha, to nigdy nie ukazuje się tam w sposób właściwy, nie staje się ideą, bo do tego musielibyśmy zaczynać z pozycji wiedzy absolutnej, do której w Fenomenologii dopiero zmierzamy. Zob. H.S. Harris: Hegel's Ladder, I: The Pilgrimage of Reason. Indianapolis 1997, s. 42.

50 G.W.F. Hegel: Fenomenologia ducha..., s. 23.

51 Ibidem.

52 Ibidem, s. 515. 


\section{Prawda $(Z 7-Z 8)$}

Hegel jak najbardziej przyjmował koherencyjną teorię prawdy, podobnie zresztą jak Schelling. Tyle tylko, że w odniesieniu do banalnego zdania dotyczącego obserwacji, takiego jak „Ziemia jest okrągła”, powiedziałby, że jest ono richtige, nie wahre. Jest to stosowne, prawdziwe, ale nie ma to dla filozofii spekulatywnej większego znaczenia. Filozofia nie chce mieć do czynienia $\mathrm{z}$ tym, co banalne. Jaką to istotę, która rozwija się do swojej właściwej postaci, miałoby wyrazić jedno zdanie? Prawda jest czymś zjednoczonym, podobnie jak rozum jest tym, co jednoczy. Prawda uwzględnia to, co fałszywe, tak jak działanie słońca uwzględnia powstanie cienia, gdzie cień jest czymś przejściowym, przechodzącym. Raz jeszcze powraca do nas kwestia całości. „Całościa jest ruch przenikania się [die sichbewegende Durchdringung] indywidualności i tego, co ogólne"53; to akurat cytowane zdanie uwikłane jest w kontekst rozważań swego rozdziału, zorientowane na zagadnienie tak zwanej Sprawy, jednak wyraża coś ważnego niezależnie od tego kontekstu ${ }^{54}$. Otóż żaden przejaw, w tym żaden przejaw prawdy, nie zatrzymuje się na długo. Całość nie jest czymś po prostu danym, lecz czymś zdobywanym przez myślenie, zawsze zdobywanym, nigdy do końca nie zdobytym, o czym Hegel przestrzegał już w Przedmowie ${ }^{55}$. A to oznacza coś bardzo konkretnego. Chodzi o to, aby rozum odnalazł $w$ tym, co jest bezpośrednio postrzeżone, formę pojęciowa ${ }^{56}$. Forma jest u Hegla myś-

53 Ibidem, s. 269.

54 Inaczej: nie wszystko, co pozostawialiśmy z Fenomenologii za sobą wraz z nadejściem nowego rozdziału, nadaje się do kosza, zniesienie zawiera w swym znaczeniu zachowanie. Oczywiście cała trudność polega na orientowaniu się w tym, jaka treść okazuje się na tyle istotna, że związana $\mathrm{z}$ nią kwestia powraca w następnych rozdziałach (ewentualnie dziełach).

55 „W studiowaniu filozofii w równym stopniu jak uprawianie rezonerstwa [räsonnierende Verhalten] przeszkadza urojenie, które nie ma charakteru rezonującego, [urojenie,] że istnieją definitywnie ustalone prawdy, co do których ten, kto jest w [ich] posiadaniu, mniema, że nie potrzebuje [już do nich] powracać, lecz przyjmuje je za podstawę i uważa, że może je wypowiadać, jak też za ich pomocą sądzić i osądzać [ruchten und absprechen]. Od tej strony jest szczególnie konieczne, by uczynić na powrót z filozofowania zajęcie poważne" (ibidem, s. 53).

${ }^{56}$ Ibidem, s. 169. A dlaczego nie może przejść od razu do pojęcia, pomijając rzecz? Oto odpowiedź: „Ponieważ Ja istnieje dla siebie tylko jako tożsamość formalna, to dialektyczny ruch pojęcia, proces określania świadomości, nie istnieje dla niej jako jej własne działanie, lecz jest sam w sobie i dla niej zmianą przedmiotu. Świadomość okazuje się dlatego różnie określona odpowiednio do różności danego przedmiotu, a jej dalszy rozwój jawi się jako zmiana określeń jej przedmiotu. Ja, podmiot świadomości, jest myśleniem. 
lana jako coś aktywnego, „drążącego”, treść jest obecna. W prawdziwym państwie nie zastanawiam się nad takim lub innym jego elementem (budynkiem, politykiem itp.), lecz nad zgodnością tego wszystkiego, co jest obecne, $\mathrm{z}$ pojęciem państwa; prawdziwe dzieło sztuki jest zgodne z pojęciem sztuki, a prawdziwy przyjaciel zgodny z pojęciem przyjaźni; całość bezpośrednio postrzeżona zgodna jest $\mathrm{z}$ tym, co wszystkim kieruje i rzecz polega na tym, aby filozofowie na przestrzeni tysiącleci potrafili dookreślić to „kierujące” - co, według Hegla, mamy już za sobą. I tu otwiera się przed nami, z jednej strony zrozumienie Z7, a z drugiej Heglowska kwestia Kanta, który ma tego w pełni nie dostrzegać; nie widzi tego, co zostało wyrażone, lecz, przeciwnie, to, co pozostaje niewyrażone. Posłuchajmy, co ma o nim do powiedzenia swym studentom: „Widzimy teraz, jak pojawia się w Niemczech myślące samo siebie, wchodzące w siebie absolutne pojęcie tak, że wszelka istotność przypada samowiedzy — idealizm, który domaga się przyznania (vindiziert) samowiedzy wszystkich momentów tego, co samo $\mathrm{w}$ sobie, ale sam pozostaje jeszcze zrazu obciążony pewnym przeciwieństwem, odróżnia jeszcze przecież ten byt sam w sobie (Ansich). Czyli filozofia Kantowska przywraca istotność samowiedzy, ale nie potrafi wyposażyć tej istoty samowiedzy, czyli tej czystej samowiedzy w żadną realność, nie potrafi wykazać w niej samej bytu; pojmuje proste myślenie jako mające $\mathrm{w}$ sobie samym różnicę, ale nie pojmuje jeszcze, że wszelka realność polega właśnie na tym rozróżnianiu; nie potrafi stać się mistrzem panującym nad jednostkowością samowiedzy; opisuje bardzo dobrze rozum, ale czyni to w bezmyślny, empiryczny sposób, który ograbia sam siebie na powrót ze swojej prawdy. [...] A jeśli już wspomina o pojęciu i nieskończonej idei, jeśli wypowiada formalne określenia pojęcia i dochodzi do tego, że w sposób konkretny żąda tych określeń, to odrzuca je z kolei jako prawdę, czyni je czymś wyłącznie subiektywnym — ponieważ już raz przyjęła skończone poznanie jako niezmienne, ostateczne stanowisko. Filozofia ta [...] zrezygnowała $\mathrm{z}$ pytania o to, co jest prawdziwe samo w sobie i dla siebie" 57 . A jaki jest w tym grzech kardynalny Kanta? „[P]rzy poznawaniu Kant ma zawsze na myśli poznający podmiot jako jednostkowy" ${ }^{\text {58. }} \mathrm{Z}$ tego wynika, że Kant uznaje, iż to, co nieskończone, nie jest dane w doświadczeniu, zarówno zewnętrznym, jak i wewnętrznym, na co Hegel zwyczajnie odpowiada: „To zależy od tego, jak się patrzy na świat; ale doświadczeniem, rozważaniem świata Kant nigdy nie nazywa nic innego niż [stwier-

Logicznym procesem określania przedmiotu jest to, co $w$ podmiocie i przedmiocie tożsa$m e$, ich absolutny związek, to, zgodnie z czym przedmiot jest dla podmiotu tym, co jego". G.W.F. Hegel: Encyklopedia nauk filozoficznych..., s. 439-440 (§ 415).

57 G.W.F. Hegel: Wyktady z historii filozofii III..., s. 505-506.

58 Ibidem, s. 525 . 
dzenie faktu], że tu stoi lichtarz, a tam leży tabakierka"59. Jak to należy rozumieć? Otóż, najprościej mówiąc, stanowisko samowiedzy, mimo że jest uwikłane w świadomość innego (co najlepiej przedstawiła relacja pana do sługi), polega na tym, że ja jestem tu - a ze mną moje myśli i moja wolność - a tam jest obcy świat, często mi wrogi (co z kolei najlepiej przedstawiła świadomość nieszczęśliwa). Stanowisko rozumu jest takie, że tu jestem ja i tam też jestem ja. To jestem ja i mój świat — to klucz do zajmowania się naukami szczegółowymi, w których badacz zapomina o swoich partykularnościach, w których nie dąży do wykazania własnej wyjątkowości, w których nie trapią go egzystencjalne problemy ${ }^{60}$ (Z8). Rozum, wyłamując się od bycia czymś jednostkowym - jako język, jako naród przestaje być tylko moim rozumem, to znaczy zmierza do bycia duchem: „Owa jedność świadomości i samowiedzy zawiera w pierwszym rzędzie jednostki jako przeświecające w sobie nawzajem ${ }^{61}$ ". Rozum sam siebie zapewnił co do tego, że poznanie wszelkiej rzeczy jest jego własnym poznaniem $^{62}$. Rozum jest więc ,jednością świadomości i samowiedzy, polegającą na tym, że duch ogląda treść przedmiotu jako samego siebie, a samego siebie jako coś, co jest samo w sobie i dla siebie określone - i w ten sposób jest rozumem, pojęciem ducha"63. Świadomość jest wszelką realnością, a to, czego nie jesteśmy świadomi, nas (nas, ludzi, nie mnie!) nie dotyczy. Niejako sprawa się tu przedstawia jak z mędrcem, który wie wszystko, bo to, czego rzekomo miałby nie wiedzieć, nie zasługuje na miano wiedzy. Najpełniejszym tego wyrazem będzie Nauka logiki, której wszystkie kategorie, nawet mechanizm czy chemizm, są jednakowo kategoriami przyrody, jak i ducha. Przy czym liczy się tu w byciu rozumem już sam rezultat, nie chodzi jeszcze o to, by to, czym rozum jest (tak jak jest opisywany w Fenomenologii) było dostępne dla samego opisywanego (np. rozum obserwujący — pierwszy moment rozumu — nie wie, że — poznając rzeczy, poznaje siebie - jedynie to przeczuwa). „Czysta abstrakcyjna wolność dla siebie puszcza wolno swoją określoność, naturalne życie duszy, jako coś równie wolnego, jako samoistny obiekt, i Ja ma najpierw wiedzę o nim jako o czymś względem niego zewnętrznym, i jest $\mathrm{w}$ ten sposób świadomością. Ja jako ta absolutna negatywność jest samo w sobie tożsamością w innobycie. Ja jest samo tym innobytem i rozszerza się na obiekt jako coś, co jest

59 Ibidem, s. 528.

${ }^{60}$ Zob. G.W.F. Hegel: Fenomenologia ducha..., s. 27-28. Eterem nauki jest wiedza o sobie i bycia z soba $w$ domu w tym, co absolutnie inne.

${ }^{61}$ G.W.F. HeGEL: Encyklopedia nauk filozoficznych..., s. 451 (§ 437).

62 Zob. P. Kalkavage: The Logic of Desire: An Introduction to Hegel's Phenomenology of Spirit. Philadelphia 2007, s. 2.

63 G.W.F. Hegel: Encyklopedia nauk filozoficznych..., s. 441 (§ 417). 
samo $w$ sobie zniesione. Jest jedna stroną stosunku i catym stosunkiem świattem, które ukazuje samo siebie i jeszcze coś innego" ${ }^{4}$. Rozum jest więc czymś kluczowym, podczas gdy u Kanta „[p]rzeszukuje się worek duszy, jakie też władze się w nim kryją; i przypadkiem natrafia się jeszcze na rozum - równie dobrze mogłoby nie być żadnego rozumu" ${ }^{95}$. Jeśli jednak to wszystko jest tylko pewnościa dotyczącą tej jedności, mamy do czynienia wyłącznie z rozumem, nie z duchem realizującym się poprzez działanie. Dlatego Hegel przestrzega: „Ale choćby rozum rył we wnętrznościach rzeczy i otwierał im wszystkie żyły, żeby wyskoczyć z nich sobie naprzeciw, to nie osiągnie [od razu] tego szczęścia, lecz musi najpierw dojść w sobie do swej ostatecznej postaci [sich vollendet haben], by dopiero potem móc jej [ihre Vollendung] doświadczyć" ${ }^{66}$. Rozum staje się duchem, kiedy pewność staje się prawdą, tym samym zarówno świadomość, samowiedza, jak i rozum są już wobec niego czymś, co jest w posiadaniu ducha, czymś, co jest ze sobą zestawiane i odróżniane ${ }^{67}$. W obliczu tego rzecz sama $\mathrm{w}$ sobie ${ }^{68}$, jeżeli $\mathrm{W}$ ogóle należałoby sobie pozwolić na to określenie, jest to Ja, które „określa siebie jako rzecz obdarzoną własnymi określeniami, własnościami" ${ }^{69}$. Albo, mówiąc inaczej, przy nieuznaniu sensowności podjęcia rozważań na temat tego, co rzekomo nigdy nie może być dostępne ludzkiej świadomości, jedyna rzecz, która jest wolna od określeń, to ta, której nic nie określa oprócz niej samej (czyli która jest swoistym causa sui), to zaś może być tylko Ja, bez względu na to, czy Ja obecne mniej lub

${ }^{64}$ Ibidem, s. $438-439$ (§ 413).

${ }^{65}$ G.W.F. Hegel: Wyktady z historii filozofii III..., s. 527. „Kant wiedział więcej niż ktokolwiek przed nim. Ale wiedział to w sposób »fałszywy« (jak to wyraził Hegel w Przedmowie), bo nie uchwycił tego, że racjonalny porządek musi w sposób niekrytyczny być, zanim w ogóle ktokolwiek będzie mógł »mieć« rozum”. H.S. Harris: Hegel's Ladder, II: The Odyssey of Spirit. Indianapolis 1997, s. 148.

66 G.W.F. Hegel: Fenomenologia ducha..., s. 170.

67 Ibidem, s. $286-287$.

68 Jeżeli zinterpretujemy rzecz samą w sobie Kanta w sposób nieco bardziej umiarkowany, mianowicie: „Nigdy nie poznajemy rzeczy w całości jej uwarunkowań” (zamiast „Nigdy nie poznajemy rzeczy jako takiej”), wtedy musimy pamiętać, że Heglowi ta interpretacja o całości uwarunkowań była obca. Hegel widzi to tak, że według Kanta rzecz w ogóle nie jest nam dostępna w zjawiskach, mamy do czynienia tylko ze zjawiskami. To podejście Hegel mógł przejąć (bezpośrednio lub za pośrednictwem idealistów) od Salomona Majmona, gdzie myślimy o tym w ten sposób: o rzeczy samej w sobie możemy pomyśleć jedynie na sposób czysto pojęciowy, to myślenie pochodzi jednak od podmiotu - używa on pojęć, które samej rzeczy nie dotyczą, są więc odzwierciedleniem samego tego podmiotu, nie rzeczy.

${ }_{69}$ G.W.F. Hegel: Nauka logiki, Tom II. Tłum. A. Landman. Warszawa 2011, s. 157-159. 
bardziej jako świadomość, samowiedza czy rozum ${ }^{70}$. Nie bez powodu Schelling wzbogacił Fichteańskie Ja w spinozjańską treść. Jedyne, co Hegel musiał zrobić, to przyjąc to w spadku po nim. Owo Ja nazwane jest czystym pojęciem, a jego najważniejsze, wynikające z siebie określenia - kategorie - opisane są w Nauce logiki, a te kategorie, jak wynika z fenomenologicznych rozważań na temat rozumu (wobec którego duch jest podniesieniem pewności do rangi prawdy), dotyczą tak mnie, jak i tego, co poza mną, ducha i przyrody. „Tylko jednostronny fałszywy idealizm każe znowu tej jedności stanąć po jednej stronie, a temu, co samo w sobie naprzeciw niej" 71 . Prawda jest ideą, która jest „W sposób istotny konkretna, ponieważ jest ona wolnym pojęciem, które określa siebie samo i tym samym określa się jako rzeczywistość" ${ }^{72}$. Prawda jest tym, co się urzeczywistnia, tak iż pojęcie czegoś i obiektywność z tym związana są jednym i tym samym. Prawda jest nieuchwytna $w$ tym sensie, że obiektywizuje sama siebie i dlatego nigdy nie jest czymś domkniętym; jej „domknięcie” jest czymś bezpośrednim, stronniczym. Prawda nie jest jednak również $\mathrm{z}$ tego powodu czymś przed nami niedostępnym — poznanie jej głębi jest równoznaczne $\mathrm{z}$ poznaniem historii ${ }^{73}$. Prawda jest samoprzywracającą się tożsamością, powracającą z wielu różnic, sprzeczności ${ }^{74}$. Ja muszę poznać historię, by poznać te sprzeczności.

Innymi słowy: przedmiot jest w pełni sobą, gdy jest w pełni wyłoniony; ale być sobą może tylko jako jaźń, tak iż przestał być przed-miotem ${ }^{75}$. Chodzi o to, by śledzić ruch obiektywnej treści (zmieniającą się postać tego, co obecne, jak galerię wspaniałych obrazów w muzeum), a nie stać jak dziecko we mgle naprzeciwko wyobrażonej rzeczy samej w sobie ${ }^{76}$. Jaźń musi rozpoznać w sobie część tego, co śledzi i to część kluczową. Jaźń musi ujrzeć odbicie w zwierciadle morza, które tropi. Dopiero wtedy jej pewność siebie może stać się jej prawdą, którą urzeczywistnia. Gdyby Hegel trwał

${ }^{70}$ Rzecz jest ubogą kategorią, ale przy zastrzeżeniu tego ubóstwa można naprzemiennie stosować kategorie Nauki logiki, tak samo, jak można było nadawać Bogu różne określenie z niej wzięte. „To, co zmysłowe, jako Coś staje się czymś Innym. Refleksyjne kierowanie się tego Czegoś ku sobie, czyli rzecz, ma wiele właściwości i jako coś jednostkowego ma ona w swojej bezpośredniości różnorodne orzeczniki" (G.W.F. HeGEL: Encyklopedia nauk filozoficznych..., s. 442 (§ 419)).

${ }_{71}$ G.W.F. Hegel: Fenomenologia ducha..., s. 166. Zob. L. Siep: Hegel's Phenomenology of Spirit. Cambridge 2014, s. 110.

${ }_{72}$ G.W.F. Hegel: Encyklopedia nauk filozoficznych..., s. 239 (§ 213Z).

73 Zob. T. Pinkard: Hegel's Phenomenology: The Sociality of Reason. Cambridge 1994, s. 265.

${ }^{74}$ G.W.F. Hegel: Fenomenologia ducha..., s. 22-23.

75 Ibidem, s. 34.

76 Zob. ibidem s. $45-46$. 
przy niepoznawalności rzeczy samej w sobie, przejście od rozumu do ducha w Fenomenologii nigdy nie byłoby możliwe.

\section{Zakończenie}

Gdzie w tym wszystkim zagubiła się myśl o rzeczy samej w sobie? Ona zagubiła się we mgle, która pozostała po odrzuceniu transcendencji. To jednak otwiera dyskusję na temat stosunku Hegla do religii, zbyt obszerną — zbyt niejednoznaczną — dla objętościowych ograniczeń tego artykułu.

Hegel chce tłumaczyć świat na jego własnych (świata) warunkach. To wszystko, co posłużyć może za wyjaśnienie kwestii zostanie wykorzystane, to wszystko, co temu przeszkadza, zostanie zepchnięte na stanowisko samowiedzy, która zmaga się sama ze sobą (jak w przypadku świadomości nieszczęśliwej). Gdy abstrahowanie od samowiedzy — jakiejkolwiek samowiedzy - zostaje postrzeżone jako takie samo dziwactwo, jak abstrahowanie od grawitacji, wtedy nie ma naprawdę miejsca na tajemnicę, bo ona staje się jej częścią, a jako część, jako to, co idzie zawsze w parze, traci na swej autentyczności. To nie był zbieg okoliczności, że to samowiedza, a nie rozum czy duch, czy wiedza absolutna, została tak bardzo podkreślona przez Hegla. To, co subiektywne oraz, nazwijmy to, ,prywatne”, zostało podniesione do rangi tego, co kształtujące i kształtowane w taki sposób, że spinozjańska substancja sama siebie określa i sobie jest dostępna, a jako taka przyjmuje tu nazwę pojęcia, a jako uhistoryczniona - ducha. Mowa o rzeczy samej w sobie jako o pozbawionej podmiotu prawdzie ma miejsce wtedy, kiedy to, co dla siebie, pozostaje poza obszarem prawdy, ale na to Hegel nigdy się nie zgodzi. Rzecz sama w sobie pozbawiona jest dla nas określeń, ale rzecz, jakakolwiek by ona nie była, ma to do siebie, że posiada dla nas pewne określenia, der Sachverhalt stanowi nagromadzenie wydawałoby się niepowiązanych ze sobą właściwości, które odnajdują swe powiązanie. Więc jeśli rzecz ta nie jest dla nas niczym, nic nas nie obchodzi, a jeśli rzecz ta ma być tylko przypomnieniem, że nigdy nie uchwycimy pełni bytu, wtedy Hegel odpowie, że to właśnie — co najwyżej — sam byt nigdy nie uchwyci własnej pełni; a co uchwycił do tej pory, o tym Hegel napisał sporo, pisząc o duchu. Wracamy u Hegla raz jeszcze do myślenia o tym, co absolutne, ale to myślenie samo nim się ukazuje, przez co przepaść między malutkim mną a wielkim absolutem zanika. I tu już więcej 
Kanta nie odnajdziemy, trzeba będzie dopiero do niego powrócić w dekadach następujących po śmierci Hegla. Tymczasem dotarliśmy do antypody, w której myśleć właściwie to myśleć jako uczestnik (nie-obcy) z uwagi na to, co samo siebie określiło. Pominięcie tego, co samo siebie określiło przede mną - pominięcie historii, dla której świadomość jest tym, co kluczowe — to zanurzenie się w pustkę mojej jaźni, która rzekomo jeszcze niczego nie określiła. Innej rzeczy samej w sobie w filozofii Hegla nie będzie.

\section{Bibliografia}

Harris H.S.: Hegel's Ladder, I: The Pilgrimage of Reason. Indianapolis 1997.

HARRIS H.S.: Hegel's Ladder, II: The Odyssey of Spirit. Indianapolis 1997.

Hegel G.W.F.: Encyklopedia nauk filozoficznych. Tłum. Ś.F. Nowicki. Warszawa 2014

Hegel G.W.F.: Fenomenologia ducha. Tłum. Ś.F. Nowicki. Warszawa 2010.

Hegel G.W.F.: Nauka logiki, Tom II. Tłum. A. Landman. Warszawa 2011.

Hegel G.W.F.: Wyktady z filozofii religii, Tom I. Tłum. Ś.F. Nowicki. Warszawa 2013.

Hegel G.W.F.: Wyktady z historii filozofii, Tom III. Tłum. Ś.F. NowICKI. Warszawa 2013.

Kalkavage P.: The Logic of Desire: An Introduction to Hegel's Phenomenology of Spirit. Philadelphia 2007.

Kant I.: Dzieła zebrane: Tom I. Pisma przedkrytyczne. Tłum. Translatorium Filozofii Niemieckiej Instytutu Filozofii UMK. Toruń 2010.

Loewenderg J.: Hegel's Phenomenology: Dialogues on The Life of Mind. La Salle 1965.

Noras A.: Kant $i$ Hegel $w$ sporach filozoficznych osiemnastego $i$ dziewiętnastego wieku. Katowice 2007.

Pinkard T.: Hegel's Phenomenology: The Sociality of Reason. Cambridge 1996.

Rockmore T.: Cognition: An Introduction to Hegel's Phenomenology of Spirit. Berkeley 1997.

Schelling F.W.J.: System idealizmu transcendentalnego: O historii nowszej filozofii (Z wykładów monachijskich). Tłum. K. Krzemieniowa. Warszawa 2015.

SieP L.: Hegel's Phenomenology of Spirit. Cambridge 2014.

Artur Jochlik - dr filozofii, związany z Instytutem Filozofii Uniwersytetu Śląskiego w Katowicach. 